\title{
DUKUNGAN KELUARGA PADA PENGOBATAN PENDERITA TB PARU MULTI DRUG RESISTANCE YANG TINGGAL DI WILAYAH KERJA DINAS KESEHATAN KABUPATEN KEPULAUAN SANGIHE
}

\section{FAMILY SUPPORTING TREATMENT MULTI DRUG RESISTANCE PULMONERY TB OF PATIENT IN THE WORKING AREA OF HEALTH DEPARMENT SANGIHE ISLAND}

\author{
Detty Jeane Kalengkongan, Grace Angel Wuaten, Agneta Sartika Lalombo \\ Program Studi Keperawatan, Politeknik Negeri Nusa Utara \\ Email:kalengkongandetty@gmail.com
}

\begin{abstract}
Abstrak: TB Multi Drug Resisntance adalah TB dengan resistensi terjadi dimana Micobacterium tuberculosis resisten terhadap rifampisin dan isoniazid dengan atau tanpa obat anti TB lainnya, Data dari Dinas Kesehatan Kabupaten Kepulauan Sangihe TB MDR sebanyak 8 kasus. Gagalnya pengobatan TB MDR adalah penderita tidak mau minum obat secara teratur dalam waktu yang lama.Keluarga mempunyai peranan yang besar untuk mendukung, dan selalu siap memberikan dukungan agar penderita rutin minum obat dan teratur dalam pengobatan. Tujuan penelitian ini menguraikan dukungan keluarga pada pengobatan penderita TB MDR yang tinggal di wilayah kerja Dinas Kesehatan Kabupaten Kepulauan Sangihe. Metode penelitian kualitatif dengan pendekatan fenomenologis. Teknik pengambilan sampel adalah purposive sampling dengan 6 informan yang mewakili keluarga. Intrumen pengumpulan data adalah peneliti sendiri serta alat penunjang seperti panduan wawancara, catatan lapangan dan alat perekam. Uji keabsahan data meliputi uji credibility,transferability, dependability dan confimability. Hasil penelitian ditemukan 3 tema yang meliputi Dukungan emosional, dukungan informasi dan dukungan penghargaan.Dari 3 tema menunjukkan bahwa sebagian besar penderita mendapatkan dukungan dari keluarga secara maksimal dengan melibatkan ekspresi rasa empati, peduli, sehingga dapat memberikan rasa nyaman.Selain itu dukungan yang diberikan berupa ungkapan penghargaan positif terhadap ide, disampaikan dalam pemecahan masalah, memberikan usul, saran, petunjuk serta pemberian informasi.Kesimpulan dukungan keluarga, petugas kesehatan serta pemegang program dapat menumbuhkan semangat penderita untuk tetap optimis menjalani pengobatan TB MDR hingga mencapai kesembuhan.
\end{abstract}

Kata Kunci: Dukungan Keluarga, Pengobatan, TB MDR

\begin{abstract}
Multy Drug Resistance TB is TB with resistance occuringin which Microbacterium tuberculosis is resistance to rifampicin and isoniazid with or without other anti TB drugs. Data from the Health office of Sangihe Island Regency, TB MDR were 8 cases. The failureof MDR TB treatment is that the patient does not want to take medication regularly for a long time. The family has a big part to support and to provide to patient take medicine regularly. The purpose of this study to describe family supporting treatment multi drug resistance pulmonery TB of patient in the working area of health deparment sangihe island. Qualitative research method with aphenomenological approach. The sampling technique was purposive sampling with 6 informants represent the family. The data collection instrument was the researcher himself as interview guider, field notes and recording devices. Data validity tesis include credibility, transferability, dependability and confimability tests. The results of the study 3 themes including emotional support, information support and appreciation support. Of the 3 themes were showed that most of the sufferers had supported from their family by involed expressions of emphaty, caring so they can provide a sense of comfort. In addition, the support provided were in the from of expressions of positive appreciation for ideas, conveyed in problem solving, giving, suggestions, insttructions, and information. Conclusion family support, health workers and program holders can foster patient enthuasiams to remain optimistic abaut undergoing MDR TB treatment to achieve recovery.
\end{abstract}

Key words: Family support, treatment, TB MDR. 


\section{PENDAHULUAN}

Tuberculosis Multi Drug Resistance (TB MDR) adalah TB dengan resistensi terjadi, dimana Microbacterium tuberculosis resisten terhadap rifampisin dan inosiazid dengan atau tanpa obat anti TB (OAT) lainnya.(WHO, 2008). Direktur Jenderal Pencegahan dan pengendalian penyakit Kemenkes RI, (Subuh, 2017) mengatakan gejala TB MDR sama dengan TB, tetapi peluang kesembuhan lebih kecil karena kebal obat lama dan kuman lebih ganas. Pasien TB MDR harus minum obat selama 24 bulan.

Laporan dari Word Health Organisation (WHO, 2016).Indonesia merupakan negara dengan jumlah kasus baru tuberculosis terbanyak kedua dengan angka prevalensi dan insiden tertinggi di dunia setelah Negara India. Data dari Kementerian Kesehatan Republik Indonesia pada tahun 2017 ditemukan jumlah kasus baru Tuberkulosis sebanyak 351.893 kasus, hal ini ada peningkatan bila dibandingkan kasus Tuberkulosis yang ditemukan pada tahun 2015 dengan jumlah sebanyak 330.729 kasus, dan data TB MDR selalu ada peningkatan. Berdasarkan data Dinas Kesehatan Kabupaten Kepulauan Sangihe terdapat 8 penderita TB MDR yang sementara menjalani pengobatan.Namun diantara penderita tersebut ada yang tidak melanjutkan pengobatan.Padahal upaya yang dilakukan pemerintah dalam menangani kasus TB MDR dalam menerapkan manajemen terpadu pengendalian TB resisten obat sudah maksimal (Kemenkes RI, 2017).

Penelitian yang dilakukan oleh (Nugroho, 2011 \& Indri, Nuraini Ati, 2018) menunjukan bahwa tidak patuhnya pasien dalam pengobatan sehingga tidak melanjutkan pengobatan.Kekambuhan atau kegagalan pengobatan inilah yang mengakibatkan MDR.

Kecenderungan pasien untuk bosan dan putus berobat saat pengobatan karena memakan waktu yang lama, merupakan salah satu factor ketidak patuhan itu sendiri.
Keluarga merupakan motivator, edukator, fasilitator, inisiator dan mediator terbesar dalam pemberi perawatan anggota keluarga yang menderita.Dukungan keluarga sangat berperan dalam rangka meningkatkan kepatuhan minum obat.Peran keluarga sangat penting dalam setiap aspek keperawatan kesehatan anggota keluarganya. Untuk itu keluarga berperan dalam menentukan cara asuhan yang diperlukan oleh keluarga (Yonanes, 2013).

Berdasarkan hasil yang ditemui peneliti saat penjajakan di lapangan, masih terdapat pasien TB MDR yang gagal menjalani pengobatan secara lengkap dan teratur.Tujuan penelitian ini menguraikan dukungan keluarga pada pengobatan penderita TB MDR yang tinggal di wilayah kerja Dinas Kesehatan Kabupaten Kepulauan Sangihe.

\section{METODE PENELITIAN}

Metode penelitian kualitatif dengan pendekatan fenomenologis. Teknik pengambilan sampel adalah purposive sampling dengan 6 informan yang mewakili keluarga. Intrumen pengumpulan data adalah peneliti sendiri serta alat penunjang seperti panduan wawancara, catatan lapangan dan alat perekam. Uji keabsahan data meliputi ujicredibility,transferability, dependability dan confimability(Sugiyono, 2009). Teknik pengumpulan data adalah wawancara mendalam dengan informan, pada saat setelah menyertujui serta menanda tangani lembar persetujuan.Dari hasil wawancara dan catatan lapangan dikumpulkan lalu ditranskripkan.Selanjutnya mengidentifikasi tema dan sub tema, kemudian menarik kesimpulan dan menyanyikan data.

\section{HASIL PENELITIAN}

Informan dalam penelitian ini berjumlah 6 orang yang merawat pasien dengan TB MDR yang tinggal serumah, seperti pada tabel 1

Tabel 1. Karakteristik Informan 


\begin{tabular}{cccll} 
Informan & Umur & J.K & Pekerjaan & Hubungan \\
\hline 1 & 48 & P & Peg. Polres & Istri \\
2 & 54 & P & IRT & Istri \\
3 & 29 & P & Peg. Honor & Ponakan \\
4 & 47 & L & Wiraswasta & Suami \\
5 & 64 & P & IRT & Ibu \\
6 & 39 & P & IRT & Istri \\
\hline
\end{tabular}

Pada tabel 1 menunjukan karakteristik penderita TB MDR.

Tabel 2. Karakteristik Penderita

\begin{tabular}{cccll} 
Responden & Umur & J.K & Agama & Pekerjaan \\
\hline H.K & 54 & L & Kr. Prot & Swasta \\
A.M & 51 & L & Kr. Prot & Tani \\
H.T & 54 & P & Kr. Prot & Guru \\
S.P & 46 & P & Islam & IRT \\
I.M & 28 & L & Islam & Peg. Honor \\
N.S & 44 & L & Islam & Tani \\
\hline
\end{tabular}

Pada penelitian ini terdapat 3 tema yang ditemui oleh peneliti berupa dukungan emosional, dukungan informasi dan dukungan penghargaan. Pada tiap-tiap tema terdapat kategori yang dapat diuraikan sebagai berikut:

\section{Tema Dukungan Emosional Keluarga}

Pada tema ini peneliti dapat mengidentifikasi tentang dukungan emosional keluarga dengan salah satu anggota keluarga yang menderita TB MDR. Ada 3 kategori yang muncul yaitu: istirahat/pemulihan, empati dan pemberian semangat. Hasil penelitian berdasarkan wawancara secara mendalam ditemukan dukungan emosionalyang diberikan informan seperti pernyataan sebagai berikut:

"Kita selalu kase inga pe suami biar tiap hari bakerja mar tetap musti jaga baistirahat dari biar sosaki tetap kerja sebagai petugas tukang sap jalan.Tiap hari pagi-pagi buta sobangun kasiang" (Informan 2)

"Torang selalu jaga bilang kalu istirahat, nanti itu rasa muntah, rasa pusing dengan perasaan yang nyanda sedap boleh tailing (Informan 4,5, 6)
"Sebagai istri kita lai sosayang liapaitua biar so saki tetap bakerja, dari mocari doi for keluarga" (Informan 2,3,5)

Selain pernyataan yang mendukung disampaikan oleh informan, namun masih ada informan ditemui dukungan yang belum maksimal seperti pernyataan:

"Akhir-akhir ini bilang sonda mampu
minum obat, yah kita bilang terserahjo
no.Sonyandu minum obat Sekarang so mudah
sekali jaga tersinggung.Kita sorasa
lelah lai dengan bapak" (Informan 1,6).

Dalam hal dukungan keluarga pada pemberian semangat, peneliti menemui sebagian besar informan yang dapat memberikan semangat pada salah satu anggota yang sakit.Hal ini teridentifikasi dengan pernyataan informan sebagai berikut:

"Kita selalu bilang minumterus itu obat, dari
sonyanda lama selesai paket, kong
somo baperiksa ulang
laboratorium"(Informan 2,3,4)

Tema Dukungan Informasi Keluarga

Pada tema ini yang berhasil peneliti identifikasi dari wawancara secara mendalam terdapat 2 kategori yang muncul berupa bentuk nasehat/saran dan cara pemecahan masalah. Adapun hasil wawancara secara mendalam ditemukan sebagian besar informan sudah.Hal ini terungkap pada pernyataan sebagai berikut:

"Paitua kasiang biar somengeluh talinga so pongoh, rasa muntah, kong itu badan jaga talome kata soalnya minum obat pe banyak ada 12-15 biji terus-terus kong tambah dengan suntik lai sampe 3 bulan. Mar kita jaga bilang sabar, kalu mosuka bae harus ikuti nasehat petugas" (Informan 2,3, 4,)

"Biar rasa muntah, pusing, badan rasa nda sedap, tetap minum obat sambil torang jaga bilang tekun untuk berdoa" (Informan $2,3,5)$

\section{Dukungan Penghargaan Keluarga}

Pada tema ini terdapat 2 kategori yang muncul yaitu: Sistem pembimbing dan penilaian positif. Dari hasil penelitian teridentifikasi ungkapan pada pernyataan informan sebagai berikut:

"Selama bapak minum obat paket saki yang sekarang beberapa bulan ini, bapak somudah 
tersinggung.Kong jaga bahalusinasi, bilang ada orang mobunuh pakita, kong sonimau jaga keluar rumah mar kita sebagai istri selalu bilang itu Cumabapak perasaan" (Informan 1)

"Waktu paitua ada sementara minum obat, selalu kita jaga kase inga tiap hari, supaya itu obat nyanda putus. Bae lai paitua dengar, biar jaga mengeluh talinga sopongoh, markita bilang paling lama-lama moiling"'(Informan 2,3,4)

"Itu paitua somalo kalau mopigi ibadah, mar kita jaga bilang musti jaga kurangi kalu bacirita supaya katu nyanda tajangke, mar paitua bilang kase bae betul dulu" (Informan 2,3)

"Petugas ada terangkan itu obat musti
terus dengan agak lama, dari ini
$\begin{aligned} & \text { penyebabsokabal kata, bakteri } \\ & \text { makang musti baru ibu pe tampa }\end{aligned}$

\section{PEMBAHASAN}

Hasil penelitian ini membahas tentang dukungan sosial diberikan keluarga yang diterima oleh penderita.

\section{Tema Dukungan Emosional}

Dukungan emosional keluarga merupakan bagian dari dukungan yang dapat melibatkan ekspresi rasa empati, peduli pada seseorang sehingga dapat memberikan rasa nyaman (Friedman, 2010).Pada penelitian ini ditemui bahwa sebagian besar keluarga sudah memberikan dukungan emosional pada salah satu anggota yang menderita TB MDR. Hal ini terungkap dari pernyataan yang disampaikan oleh informan bahwa keluarga selalu menyarankan untuk beristirahat demi pemulihan sakit yang dialami oleh karena hal ini dapat membantu penderita untuk tidak memikirkan hal-hal yang dapat memicu kecemasan dan stress. Begitu juga dengan rasa empati dan pemberian semangat yang diberikan keluarga, dimana mereka turut merasakan tentang apa yang dialami oleh penderita, apalagi dengan bermacam-macam keluhan yang disampaikan dimana seakan-akan merasa kecewa dan putus asa dengan penyakit yang dialami serta pengobatan yang lama dan menimbulkan efek yang tidak menyenangkan. Hal ini terungkap dari hasil wawancara dengan informan yang mengatakan bahwa penderita mengalami rasa cemas dengan keluhankeluhan yang diungkapkan, sehingga tidak dapat beristirahat. Penelitian ini didukung oleh Setianingsih,F.D \& Makmuroch, Andayani, T.R. (2011) menyatakan bahwa terdapat hubungan yang sangat signifikan antara dukungan sosial keluarga terhadap kesembuhan TB MDR. Lebih lanjut hasil penelitian dari Maulidia, Desy. F., \& Nia, D. Karyadi (2014), menyebutkan bahwa dukungan pihak keluarga dengan memberikan perhatian yang penuh dalam proses perawatan dan pengobatan banyak membantu dalam kelanjutan kepatuhan minum obat penderita TB. Hasil penelitian ini didukung dengan penelitian yang dilakukan oleh Rumimpunu, R., Franckie, R.R. Maramis., Febe, F. Kolibu (2015), dengan hasil penelitian terdapat hubungan dukungan keluarga dengan kepatuhan berobat penderita TB. Penelitian ini juga sejalan dengan hasil penelitian yang dilakukan oleh Maria, Ulfa (2011), ditemui ada 1 partisipan yang memberikan dukungan semangat dan membesarkan hati penderita.Peneliti juga menemukan bahwa dukungan yang diberikan keluarga pada salah satu anggota yang menderita TB MDR, dalam bentuk perhatian yang diberikan seperti mendengarkan semua keluhan-keluhan yang disampaikan oleh penderita.Selain hal tersebut ditemui juga pada penelitian ini ada 2 informan yang belum maksimal dalam dukungannya.Hal ini terungkap dari hasil wawancara secara mendalam pada kedua informan dimana tergambar dalam ekspresi wajah, adanya keragu-raguan dengan mengatakan bahwa mereka juga sering merasakan kelelahan dalam merawat salah satu anggota keluarga yang menderita TB MDR.Belum lagi dengan bermacam-macam keluhan yang disampaikan oleh penderita.Hal ini bertentangan dengan pernyataan dari Friedman (2010), bahwa salah satu fungsi keluarga yaitu cinta dan kasih sayang. Dimana keluarga memberikan landasan yang kokoh terhadap hubungan suami istri, orang tua dan anak-anaknya, serta hubungan keakraban antara generasi sehingga keluarga 
menjadi tempat utama bersemainya kehidupan yang penuh cinta kasih lahir dan batin. Saat seseorang didiagnosa resisten terhadap obat TB MDR, maka pengobatan yang diperlukan akan memakan waktu yang lama. Hal ini membutuhkan kesabaran dan perhatian dari keluarga kepada penderita.Dan lebih kompleks dengan efek samping yang lebih berat.Pengobatan yang lama menyebabkan penderita sering terancam putus berobat.Selama masa penyembuhan dengan berbagai alasan mengatakan tentang perasaan yang dialami seperti mual, muntah, pusing, pendengaran terganggu, terasa nyeri di seluruh badan, mudah lelah, lemas, lesu dan sesak nafas.Maka disaat inilah dibutuhkan dukungan keluarga agar penderita tidak merasa cemas dan putus asa. Penelitian ini didukung oleh Nugroho, F.S., Zahroh, S., \& Sakundano, A. (2018), dengan hasil penelitian ditemui 2 informan menyatakan bahwa tidak menganjurkan untuk pengobatan selanjutnaya pada salah satu anggota keluarga yang menderita TB MDR karena merasakan efek samping yang berat. Sehingga memutuskan untuk menghentikan pengobatan. Penelitian ini tidak sama dengan penelitian yang dilakukan oleh Maulana, Shaupatus Sara (2017), menyatakan bahwa dukungan emosional keluarga yang berupa rasa empati, perhatian yang diterima dapat memotivasi penderita dalam hal pengobatan, dengan hasil baik $(64,5 \%)$. Penelitian ini didukung oleh Ainiyah, N.A., Soedarsono.,\& Prilina, Umiastuti (2019) menunjukan ada hubungan yang sangat signifikan antara dukungan keluarga dengan kepatuhan minum obat penderita TB MDR.

\section{Tema Dukungan Informasi}

Dukungan informasi yang dilakukan keluarga dalam meningkatkan kesehatan anggota keluarga yang sakit, berupa saran, nasehat, sumber informasi, serta melibatkan orang yang dihormati dalam proses penyampaian informasi yang didapatkan kepada anggota keluarga yang membutuhkan Smet, Bart), 2009). Dukungan keluarga sangat membantu penderita untuk sembuh. Hal ini terlihat dari pernyataan informan yang mengatakan selalu mengingatkan penderita untuk minum obat, juga ditunjang oleh petugas kesehatan yaitu Pengawas Minum Obat (PMO) yang selalu menujukan perhatian dengan mengunjungi penderita maupun melalui telepon/sms, untuk mengingatkan waktu minum obat. Penelitian ini sama dengan penelitian yang dilakukan oleh Saraswati.W (2012). Menyatakan bahwa peran, nasehat keluarga dan petugas PMO untuk mendukung kesembuhan penderita TB MDR.Begitu juga dalam mengatasi masalah, sesuai dengan hasil wawancara yang ditemui bahwa ada 2 orang penderita tidak melanjutkan pengobatan oleh karena adanya gangguan pendengaran.Hal ini memungkinkan bahwa pemahaman serta pengetahuan tentang pengobatan penyakit TB MDR masih kurang. Penelitian ini sama dengan penelitian dari Nugroho, R.A (2011), dengan hasil dari 28 pasien TB MDR ada 2 pasien yang telah putus pengobatan dan belum bersedia untuk melanjutkan pengobatan kembali. Salah satu faktor yang mempengaruhi pada dukungan keluarga adalah pendidikan.Tingkat pendidikan seseorang termasuk juga prilaku akan pola hidup, terutama dalam memotivasi sikap dan berperan dalam perkembangan kesehatan. Hal ini sejalan dengan penelitian yang dilakukan oleh Indri, dan Nuraini, I.A (2018), dengan hasil penelitian menyatakan bahwa jumlah responden dengan pendidikan diatas SMA dengan hasil baik (67\%) terhadap dukungan keluarga pada pengobatan penderita TB MDR.

\section{Tema Dukungan Penghargaan}

Dukungan penghargaan terjadi melalui ungkapan positif pada individu.Dorongan untuk maju atau memberikan penghargaan terhadap ide/gagasan atau yang disampaikan individu (Friedman, 2012).

Hasil penelitian ditemui bahwa keluarga sebagai system pembimbing yang sesuai dengan fungsinya untuk membimbing, mengarahkan dalam perawatan serta pengobatan salah satu anggota yang sakit dalam proses penyembuhan sudah menjalankan tugasnya. Hal ini terungkap pada pernyataan yang disampaikan oleh informan saat wawancara dengan peneliti, bahwa 
keluarga bertindak sebagai pemberi pengakuan dan perhatian kepada anggota keluarga untuk membimbing, memberikan dorongan untuk maju dan persetujuan dengan gagasan atau perasaan penderita kepada hal yang positif.Hal ini sejalan dengan Laitaful Muna dan Umbatus Soleha (2015), menyatakan bahwa dukungan penghargaan yang sudah diberikan oleh keluarga kepada anggota yang sakit, dapat memberi pengakuan positif. Namun disisi lain ada keluarga yang ditemui belum sepenuhnya menjalankan fungsi sebagai pembimbing dalam menangani penderita. Soal tidak menjalankan pengobatan dengan alasan bahwa penderita tidak kuat dengan efek samping yang dirasakan. Penelitian ini sama dengan penelitian dari Kumala, Sari. F., Kusyogo, Cahyo.,\& Aditya Kusumawati (2018), menyatakan bahwa sebanyak 18 responden TB MDR terdapat $(75 \%)$ penderita merasakan efek samping dari mengkonsumsi obat TB MDR. Dukungan keluarga merupakan salah satu faktor yang mempengaruhi kepatuhan untuk pengobatan. Keluarga perlu memberikan dukungan positif untuk melibatkan diri sebagai pendukung pengobatan sehingga adanya kerjasama dalam pemantauan pengobatan antara petugas dan anggota keluarga yang sakit (Friedman, Marilyn, M. 2014). Sikap positif keluarga dalam memberikan motivasi bagi pengobatan penderita dipengaruhi oleh pemahaman keluarga terhadap penyakit TB MDR atau proses pengobatan yang dijalani anggota keluarganya. Penelitian ini tidak sama dengan penelitian yang dilakukan oleh Muh, Suyuti., Riskiyani, Shanti, Rachman., \& Watief, A (2013), menyebutkan bahwa ada hubungan yang positif dan bermakna antara dukungan sosial keluarga dengan kepatuhan minum obat. Penelitian ini sama dengan penelitian yang dilakukan oleh Asra, Septia., Siti, Rahmalia., Febriana, Sabrian (2014), mengatakan bahwa dukungan keluarga memiliki hubungan dengan kepatuhan minum obat.

\section{KESIMPULAN}

Dukungan sosial keluarga pada pengobatan penderita TB MDR dimulai dari dukungan emosional, fase ini berekspresi dari afeksi, kepercayaan, perhatian dan perasaan yang didengarkan.Selanjutnya adalah fase dukungan informasi.Pada fase ini pemberian nasehat, petunjuk, saran dan informasi. Kemudian dukungan penghargaan, dimana pada fase ini ungkapan penghargaan yang positif individu dan perbandingan positif individu dengan individu lain. Saran dukungan keluarga perlu ditingkatkan dalam menumbuhkan semangat penderita untuk tetap optimis menjalani pengobatan hingga mencapai kesembuhan yang maksimal

\section{DAFTAR RUJUKAN}

Ainiyah, N. A., Soedarsono.,\& Pirlina, Umiastuti. 2019. Hubungan peran keluarga dan kepatuhan pasien TB MDR di RSUD Dr. Soetomo Surabaya.Jurnal Respirasi Vol 5.No1 (online) https://e-journalunair.ac.id/JR/article/view/11457. Diakses tanggal 18 Oktober 2019

Asra, Septia. Siti, Rahmalia., Febriana, Sabrian. 2014. Hubungan dukungan keluarga dengan kepatuhan minum obat pada penderita TB Paru (online) https://media.neliti.com. Diakses tanggal 18 Oktober 2019.

Friedman. 2010. Buku Ajar Keperawatan Keluarga. Riset Teori dan Praktik. EGC: Jakarta.

Friedman., Marilyn, M. 2014. Buku Ajar Keperawatan Keluarga, Riset, Teori dan Praktik. EGC: Jakarta.

Indri, Nuraini, Ati. 2018. Gambaran dukungan dan peran keluarga sebagai PMO dalam pencegahan TB MDR di Wilayah Kerja Puskesmas gang Kelor kota Bogor. Jurnal Riset Kesehatan Vol 10.(online) https://doi.org/10.34011/juriesbdg.Diakses tanggal 12 Oktober 2019.

Kementerian KesehatanRI. 2017. Infodatin Pusat Data dan Informasi. Kemenkes RI. https://ppl.depkes.go.id/indexphp.Diakses tanggal 26 Februari 2019. 
Kumala, Sari. F., Kusyogo, Cahyo., \& Aditya, Kusumawati. 2018. Gambaran prilaku pasien sembuh TB MDR di kota Semarang.Journal kesmas vol. 6 nomor 5 (online) https;//ejournal3.undip.ac.id. Diakses tanggal 2 Oktober 2019.

Latifaful, Muna.,\& Umdatus, Soleha. 2015. Motivasi dan dukungan sosial keluarga mempengaruhi kepatuhan berobat pada pasien TB Paru di Poli Paru BP4 Pamekasan (online https://journal2.unusa.ac.id. Diakses tanggal 16 Oktober 2019.

Maria,Ulfa. 2011. Hubungan Dukungan keluarga dengan kepatuhan minum Obat pada pasien TB di Wilayah kerja Puskesmas Pamulang kota Tangerang. Journal Respository (online) https://respository.uinjkt.ac.id/dspace/12345679 /25594 Diakses tanggal 16 Oktober 2019.

Maulidia, Desy.F.,\& Nia, D. Karyadi. 2014. Hubungan Antara Kepatuhan Minum Obat pada penderita Tuberkulosis di Wilayah Ciputat. Jurnal respository (online) https://repository.uinjk.ac.id/dispace/handle/123 456789/25510. Diakses tanggal 16 Oktober 2019.

Muh, Suyuti., Riskiyani, Shanti., Rachman., \& Watief, A. 2013. Dukungan sosial penderita TB Paru di Wilayah kerja Puskesmas Ajangale Kabupaten Bone. Jurnal (online) www.sematicscholer.org.pdf. Diakses tanggal 10 Oktober 2019

Nugroho.2011. Studi Kualitatif Factor yang melatar belakangi Drop out pengobatan TB Paru. Jurnal Kesehatan Masyarakat 7. (online) Journal.unnes.ac.id. Diakses tanggal 10 Oktober 2019

Nugroho, F.S., Zahroh, S., \& Sakundarmo, A. 2018. Gambaran prilaku pengobatan pasien TB MDR fase intensif di RS DR.Moewar di Surakarta. Jurnal Kes.Vol.11.No 1. (online) http://journal.ums.ac.id. Diakses tanggal 18 Oktober 2019

Permatasari, R. 2018. Pengalaman Klien yang menjalani pengobatan fase Wilayah kerja Puskesmas Taji Magetan Jurnal

TB Paru intensif di Kabupaten (online) http://respository.unair.ac.id. Diakses tanggal 16 Oktober 2019

Rumimpunu, Rinny., Franckie, R. R.Maramis.,Febe, K. Kolibu. 2015. Hubungan dukungan keluarga dan dorongan petugas kesehatan dengan kepatuhan berobat penderita Tuberculosis Paru di Puskesmas Likupang Kabupaten Minahasa
Utara. Jurnal Kesmas volume7 Nomor 4 (online) https://ejournal.Unsrat.ac.id. Diakses tanggal 12 Oktober 2019

Saraswati,W. 2012. Gambaran dukungan social keluarga terhadap klien Tuberculosis paru yang berobat di Poli Paru Puskesmas Jakarta.Tesis. Jakarta Universitas Indonesia.

Septia, A., Siti Rahmalia., \& Febriana, Sabrian. 2014. Hubungan dukungan keluarga dengan kepatuhan minum obat pada penderita TB Paru. Jurnal (online) https://www.neliti.com. Diakses tanggal 18 Oktober 2019

Setyaningsih, F.D., \& Makmuroch, Andayani, T. R. 2011.Hubungan antara emosional keluarga dengan minum obat penderita TB MDR di wilayah Ciputat. Jurnal(online) https://respository.uinjkt.ac.id. pdf. Diakses tanggal 15 Oktober 2019

Shaupatus, sara. Maulana. 2017. Hubungan keluarga terhadap kepatuhan minum obat pada penderita TB MDR di Puskesmas Umbulharjo Yogyakarta. Jurnal (online) http://digilib.unisayogya.ac.id/3968 Diakses tanggal 18 Oktober 2019

Smet, Bart. 2009. Psikologi Kesehatan. Jakarta: Grasindo

Subuh, M. 2017. Manajemen terpadu pengendalian TB resisten obat (MTPRO). https://depkes.go.id.indexphb. Diakses tanggal 27 Februari 2019

Sugiyono.2009. Metode Penelitian Kuantitatif, ualitatif Riset \& Development. Bandung: ALFABETA

Sugiyono.2012. Memahami Penelitian Kualitatif. Bandung: ALFABETA

WHO, Report. 2008.GlobalTuberculosis 2008 Surveilance, Planning, Financing, Genewa,Switzerland. http://www.maxmanroe.com. Diakses tanggal 23 Februari 2019

WHO. 2016. Guidelines for The Orogrammatic drug Resistant Tuberculosis Emergency Edition, Geneva 2008. Http://www.maxmanroe.com. Diakses tanggal27 Februari 2019

WHO. 2016. Dalam Tarigan.J. Epidemiologi TB MDR. http://www.aldomedika.com. Diakses tanggal 14 Maret 2019

Yohanes, D. 2013. Care Family Nursing. Yogyakarta: Nuha Medika 
64 Jurnal Ilmiah Sesebanua, Volume 4, Nomor 2, November 2020, hlm. 57-63 